\title{
Body Weight Gain and Carcass Quality of the Hybrid Chicken Derived from the Crossing between Female $F_{1}$ Kampung Super and Male $F_{1}$ Kampung-Broiler
}

\author{
Utin Elsya Puspita ${ }^{1}$, Hendry T. S. S. G. Saragih $^{2}$, Tety Hartatik ${ }^{3}$, Budi Setiadi Daryono ${ }^{*}$ \\ 1)Laboratory of Genetics and Breeding, Faculty of Biology, Universitas Gadjah Mada, Yogyakarta 55281, Indonesia \\ 2) Laboratory of Animal Structure and Development, Faculty of Biology, Universitas Gadjah Mada, Yogyakarta 55281, Indonesia \\ 3)Laboratory of Animal Genetics and Breeding, Faculty of Animal Science, Universitas Gadjah Mada, Yogyakarta 55281, Indonesia \\ * Corresponding author, email: bs_daryono@mail.ugm.ac.id
}

Submitted: 28 October 2020; Accepted: 17 April 2021; Published online: 04 June 2021

\begin{abstract}
This research was conducted to observe the body weight gain and carcass quality of the hybrid chicken derived from the crossing between female $\mathrm{F}_{1}$ Kampung Super and male $F_{1}$ Kampung-Broiler. The weekly weight gain for seven weeks and carcass quality, including breast yield, protein content, lipid content, moisture, and $\mathrm{pH}$ were measured with each group consists of six individuals. The chickens were slaughtered for meat quality measurements on the $7^{\text {th }}$ week. The results showed that the hybrid chickens' weight at the $7^{\text {th }}$ week $(888.22 \pm 139.63)$ was higher than layer $(467.06 \pm 85.7)$ and pelung (436.39 \pm 42.33$)$. The hybrid chicken's breast yield (3.20\%) was significantly higher than pelung's $(1.66 \%)$. These characteristics of hybrid chicken breast muscle lead to the conclusion that hybrid chicken is a potential alternative meat-type chicken with local chicken meat characteristics and has relatively fast growth.
\end{abstract}

Keywords: breast yield, chicken breeding, hybrid chicken, meat quality, weekly weight gain

Growth performance and carcass traits are essential for poultry production, especially for supporting high production and lower market price (Anh et al. 2015). The continuous growing demand for poultry meat puts more insistence on producers to improve chicken production, including growth rate and feed conversion (Petracci et al. 2015). The demand for poultry meat production has led the development of the commercial breed, which is widely known as broiler, to very rapid growth.

The selection of meat-type chicken is primarily focused on the increased growth performances and improved body composition. To fulfil the demand of dietetic products, the producers are demanded to increase the breast meat yield and to lower fat content (Berri et al. 2001). Hybrid chicken is derived from crossing between different types of parental lines. The crossing between native chicken and commercial meat-type chicken results in some advantages, including higher growth rate, better feed conversion ratio, 
and higher carcass yield compared to the native chicken (Sokolowicz et al. 2016).

Pelung is one of the Indonesian native chicken domesticated in Cianjur, West Java. As reported in Nataamijaya (2010), pelung has the highest weight of all Indonesian native chickens, which can reach $2.20 \mathrm{~kg}$ on week 20. It is also reported in Saragih et al. (2019) that pelung is a potential native breed for meat production. Several studies have been conducted to improve the growth performance and production of pelung by utilizing selective breeding, such as the crossing between female broiler and male pelung (Saragih et al. 2017) to increase the body weight and the crossing between female layer and male pelung (Puspita et al. 2017). But, there is still no observation on the offspring of both type of F1, especially on body weight and carcass characteristics.

Meat is one of the most nutritious foods that is considered essential to optimal human growth and development. As one of the animal-based food, poultry contains desirable characteristics, including low lipid content and high concentrations of polyunsaturated fatty acids, which are essential to meet the consumers' health considerations (Barbic et al. 2014). Poultry meat quality is governed by several factors including genetics, feeding, husbandry, pre-slaughter handling, stunning, slaughter procedures, chilling, processing and storage conditions that interacts each other, resulting in different conditions of the meat (Milicevic et al. 2015). Previous studies reported different meat quality among different breeds that strongly indicated the correlations with different genetic characteristics. Those meat qualities include breast muscle weight, moisture, protein content, lipid content, and pH value (Lonergan et al. 2003; Le Bihan-Duval et al. 2008).

This study aims to observe the effect of breeding of pelung with broiler and layer chickens on the body growth and meat characteristics of the hybrid chicken and its potentials as the new alternative for meat-type chicken.

Four chicken groups were involved in this study: broiler as the commercial meat-type (positive control), layer as the negative control, while pelung and the hybrid chicken derived from crossing between pelung and broiler and layer. The pedigree chart and the breeding results are presented in Figure 1. Six day-old-chicks (DOCs) from each chicken type were housed with a semi-intensive system and kept under standard management conditions. The access to water and feed were provided ad libitum along with the experimental term. The DOCs were fed with starter feed BR1 from Japfa Comfeed Indonesia Tbk (Table 1).

Table 1. Nutrition fact chicken feed used in this research (BR1 Japfa Comfeed from PT. Japfa Comfeed Indonesia Tbk).

\begin{tabular}{lc}
\hline \multicolumn{1}{c}{ Nutrients } & Concentration \\
\hline Crude Protein & $21.5-22.5 \%$ \\
Water & Max. $12 \%$ \\
Fat & Min. $5 \%$ \\
Crude Fiber & Max. $5 \%$ \\
Ash & Max. $7 \%$ \\
Calcium & $0.8-1.1 \%$ \\
Phosphor & Min. $0.5 \%$ \\
Metabolic Energy & $2950-3050 \mathrm{Kcal} / \mathrm{Kg}$ \\
\hline
\end{tabular}

Body weight was measured every week started directly post-hatch until week 7. The Research Ethics Commission, Faculty of Veterinary Medicine, Universitas Gadjah Mada, Indonesia has approved all of the protocols 


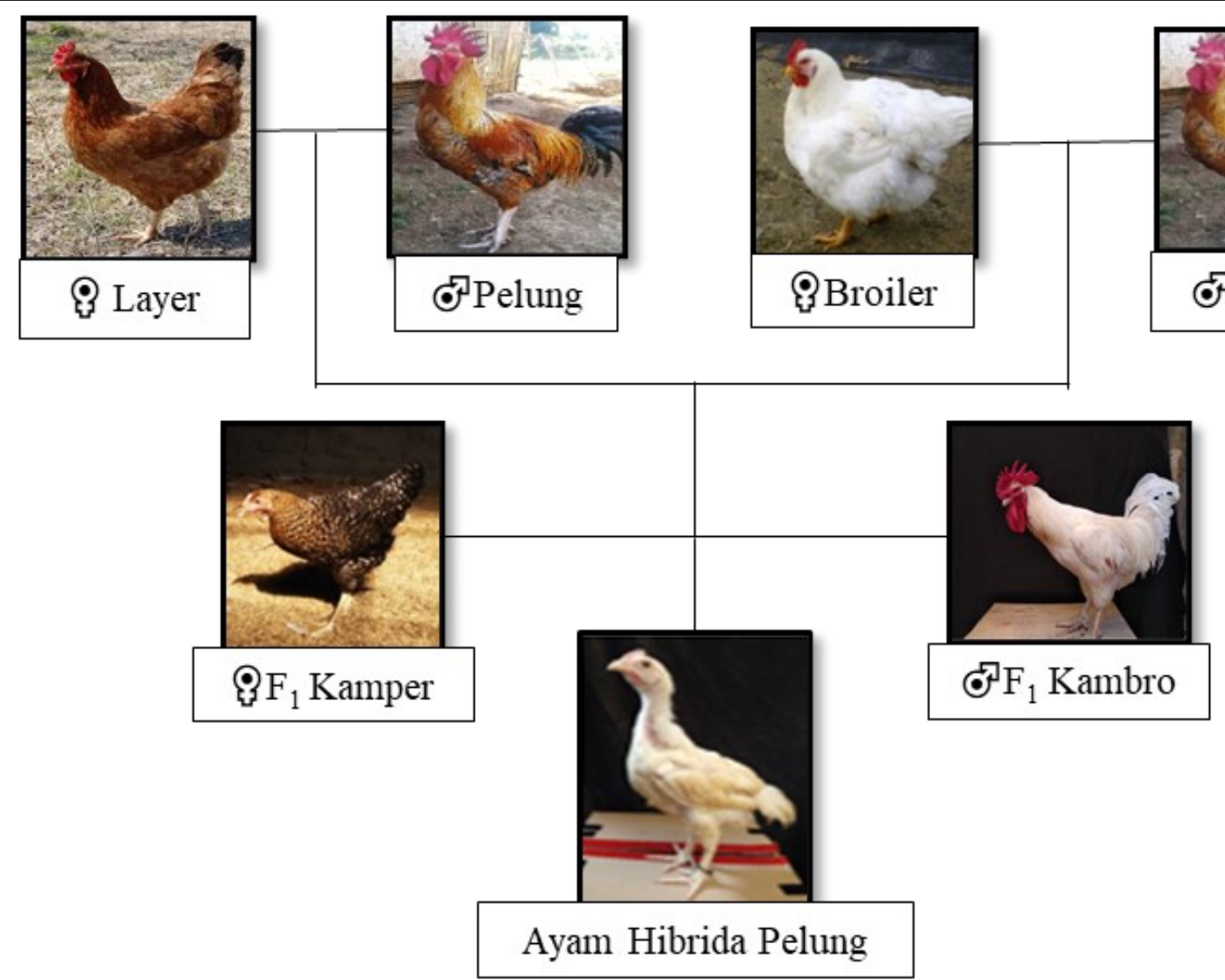

Figure 1. The hybrid chicken pedigree chart derived from the crossing between female $F_{1}$ Kamper and male $F_{1}$ Kambro.

conducted in this research (Ethical clearance No. 0105/EC-FKH/ Eks./2019).

Six chickens from every type were randomly chosen for breast yield and carcass quality measurement. Every group consisted of three males and three females. Before slaughtered, chickens were weighed and then terminated via vena jugular cutting. The total chicken breasts (right and left, pectoralis major and minor) were collected and weighed. Approximately $30 \mathrm{~g}$ of each sample was used for carcass quality analysis.

Breast muscle samples of early post-hatch chicks: post-hatch day 1, day 3 , and day 5 (then mentioned as $\mathrm{P} 0, \mathrm{P} 3$, and P5, respectively) were traced on a piece of plastic sheet and then traced on a paper to be scanned for measurement. The measurement was conducted using ImageJ software.

Fat, moisture and protein were measured using FOSS FoodScan ${ }^{\mathrm{TM}}$ Near-Infrared (NIR) Spectrophotometer (FOSS North America, 8091 Wallace Rd, Eden Prairie, MN 55344, USA) with AOAC Official Method 2007 (AOAC International 2007). pH value was measured using standardized pH meter HI 9811X Piccolo (Hanna Instrument, USA). The test was conducted at the Laboratory of Meat Science and Technology, Faculty of Animal Science, Universitas Gadjah Mada, Indonesia.

The data obtained from this study were analyzed using one-way ANOVA using SPSS 22.0 software (IBM Corporation, New York, USA) with the probability values $p<0.05$ to assume the statistical significance.

The hybrid chicken breeding was conducted to realize the breeding goals mentioned by Wang et al. (2012), such as increased growth rate, decreased abdominal fat, great skeletal system growth and development, and better health. We used broiler, layer, and pelung as parental types and control groups to meet the goals. The hybrid chicken used in this study was derived from a crossing between female $F_{1}$ Kampung Super derived from female layer and male pelung (Puspita et al. 2017) and male $F_{1}$ hybrid derived from 
crossing between female broiler and male pelung (Saragih et al. 2017). The feed used in this study was the standard broiler feed as served in Table 1. The use of this diet is to eliminate the negative effect on body weight gain due to an unsuitable diet. Pauwels et al. (2015) reported that, unlike slow-growing chicken, the fast-growing broiler is low in diet flexibility, and a significant negative effect was found on the fast-growing broiler body weight that was given a scavenger diet.

The bodyweight growth measurement of all chickens in this study was started directly after hatching until week 7 . The early growth of chickens was measured at day 0,3 and 5 post-hatches (then mentioned as P0, P3, and P5, respectively) to observe the total body weight and breast yield as presented in Table 2. The broiler chicken had the highest body and breast weight among all chicken breeds at P0, P3, and P5. On the other hand, hybrid chicken showed higher body and breast weight than layer and pelung at P3 and P5 ( $p>0.05)$. However, as shown in Table 3, hybrid chicken breast yield percentage did not show a significant difference with layer chicken at P5.

Dixon et al. (2016) reported that chick's early development might have an important effect throughout life. Several factors have been reported to play an important role in early body weight growth, such as genetic selection from different breeds (Buzala et al. 2015). On the other hand, Everaert et al. (2010) reported that protein nutrition plays a big role in the early body weight growth of broiler chicken. As shown in Table 3, all individuals observed in this study encountered breast area enlargement. Velleman (2007) explained that post-hatch muscle growth happens due to hypertrophy due to satellite cell nuclei recruitment.

The chickens then continued being kept and weighed weekly until week seven and slaughtered for meat quality analysis. The weekly growth of all groups starting from week one to week seven is presented in Table 4 and the weekly weight gain from week 0 to week seven is shown in Table 5 . Weekly growth of broiler chicken was consistently the highest among the others for seven weeks. On the other hand, hybrid chicken followed in the

Table 2. Early weight and muscle growth comparison among chicken breeds $(n=3)$.

\begin{tabular}{ccccccc}
\hline \multirow{2}{*}{$\begin{array}{c}\text { Chicken } \\
\text { Breeds }\end{array}$} & \multicolumn{3}{c}{ Total Weight $(\mathrm{g})$} & \multicolumn{3}{c}{ Breast Muscle Weight (g) } \\
\cline { 2 - 7 } & P0 & P3 & P5 & P0 & P3 & P5 \\
\hline Pelung & $27.96 \pm 3.33^{\mathrm{a}}$ & $36.00 \pm 1.00^{\mathrm{a}}$ & $41.00 \pm 0.00^{\mathrm{a}}$ & $0.34 \pm 0.04^{\mathrm{a}}$ & $0.620 \pm 0.04^{\mathrm{b}}$ & $0.680 \pm 0.08^{\mathrm{a}}$ \\
Broiler & $40.83 \pm 2.48^{\mathrm{d}}$ & $85.00 \pm 13.53^{\mathrm{d}}$ & $87.33 \pm 9.50^{\mathrm{d}}$ & $0.50 \pm 0.02^{\mathrm{c}}$ & $2.607 \pm 0.52^{\mathrm{d}}$ & $4.700 \pm 1.44^{\mathrm{d}}$ \\
Layer & $38.93 \pm 0.62^{\mathrm{c}}$ & $39.00 \pm 3.46^{\mathrm{b}}$ & $54.33 \pm 5.69^{\mathrm{b}}$ & $0.50 \pm 0.06^{\mathrm{c}}$ & $0.613 \pm 0.11^{\mathrm{a}}$ & $1.727 \pm 0.29 \mathrm{~b}$ \\
Hibrida & $35.06 \pm 3.15^{\mathrm{b}}$ & $45.00 \pm 3.00^{\mathrm{c}}$ & $60.00 \pm 4.00^{\mathrm{c}}$ & $0.41 \pm 0.03^{\mathrm{b}}$ & $0.830 \pm 0.11^{\mathrm{c}}$ & $1.920 \pm 0.11^{\mathrm{c}}$ \\
\hline
\end{tabular}

a-dMeans with the different superscripts in the same column are significantly different $(p<0.05)$.

Table 3. Individual breast muscle area in early post-hatch chicken $(n=3)$.

\begin{tabular}{lcccccc}
\hline \multirow{2}{*}{ Chicken Breeds } & \multicolumn{3}{c}{ Breast Muscle Area $\left(\mathbf{c m}^{\mathbf{2}}\right)$} & \multicolumn{3}{c}{ Breast Yield (\%) } \\
\cline { 2 - 7 } & \multicolumn{1}{c}{ P0 } & P3 & P5 & P0 & P3 & P5 \\
\hline Pelung & $0.878 \pm 0.06^{\mathrm{a}}$ & $1.500 \pm 0.18^{\mathrm{a}}$ & $2.191 \pm 0.07^{\mathrm{a}}$ & $1.22^{\mathrm{a}}$ & $1.72^{\mathrm{b}}$ & $1.66^{\mathrm{a}}$ \\
Broiler & $1.685 \pm 0.21^{\mathrm{c}}$ & $5.752 \pm 0.29^{\mathrm{d}}$ & $8.440 \pm 0.68^{\mathrm{d}}$ & $1.22^{\mathrm{a}}$ & $3.07^{\mathrm{c}}$ & $5.38^{\mathrm{c}}$ \\
Layer & $1.303 \pm 0.03^{\mathrm{b}}$ & $2.194 \pm 0.23^{\mathrm{b}}$ & $3.136 \pm 0.33^{\mathrm{b}}$ & $1.30^{\mathrm{b}}$ & $1.57^{\mathrm{a}}$ & $3.18^{\mathrm{b}}$ \\
Hibrida & $1.373 \pm 0.28^{\mathrm{b}}$ & $2.324 \pm 0.08^{\mathrm{c}}$ & $3.241 \pm 0.22^{\mathrm{c}}$ & $1.17^{\mathrm{a}}$ & $1.84^{\mathrm{b}}$ & $3.20^{\mathrm{b}}$ \\
\hline
\end{tabular}

a-dMeans with the different superscripts in the same column are significantly different $(p<0.05)$. 
Table 4. Chicken weight gain for seven weeks (g; $\mathrm{n}=18)$.

\begin{tabular}{lccccccc}
\hline Chicken & \multicolumn{7}{c}{ Weight Per Week $\mathbf{( g} ; \mathbf{n}=\mathbf{1 8})$} \\
\cline { 2 - 8 } Breeds & $\mathbf{1}$ & $\mathbf{2}$ & $\mathbf{3}$ & $\mathbf{4}$ & $\mathbf{5}$ & $\mathbf{6}$ & $\mathbf{7}$ \\
\hline Pelung & $46.22 \pm 5.1^{\mathrm{a}}$ & $92.56 \pm 10.6^{\mathrm{b}}$ & $129.06 \pm 17.6^{\mathrm{b}}$ & $189.44 \pm 23.0^{\mathrm{b}}$ & $230.89 \pm 27.0^{\mathrm{b}}$ & $325.33 \pm 45.7^{\mathrm{b}}$ & $467.06 \pm 85.7^{\mathrm{b}}$ \\
Broiler & $60.44 \pm 3.2^{\mathrm{d}}$ & $123.06 \pm 23.19^{\mathrm{c}}$ & $322.11 \pm 75.68^{\mathrm{d}}$ & $521.11 \pm 88.62^{\mathrm{d}}$ & $775.33 \pm 96.03^{\mathrm{d}}$ & $1002.94 \pm 131.52^{\mathrm{d}}$ & $1300.83 \pm 191.05^{\mathrm{d}}$ \\
Layer & $51.33 \pm 1.91^{\mathrm{c}}$ & $83.72 \pm 7.27^{\mathrm{a}}$ & $118.94 \pm 17.04^{\mathrm{a}}$ & $176.11 \pm 25.77^{\mathrm{a}}$ & $224.17 \pm 25.68^{\mathrm{a}}$ & $322.89 \pm 38.55^{\mathrm{a}}$ & $436.39 \pm 42.33^{\mathrm{a}}$ \\
Hybrid & $50.61 \pm 3.35^{\mathrm{b}}$ & $122.39 \pm 3.35^{\mathrm{c}}$ & $178.33 \pm 30.56^{\mathrm{c}}$ & $279.06 \pm 40.51^{\mathrm{c}}$ & $480.11 \pm 67.24^{\mathrm{c}}$ & $651.61 \pm 99.88^{\mathrm{c}}$ & $888.22 \pm 139.63^{\mathrm{c}}$ \\
\hline
\end{tabular}

a-d Means with the different superscripts in the same column are significantly different $(\mathrm{p}<0.05)$.

Table 5. Weekly weight gain among chicken breeds ( $\mathrm{g} ; \mathrm{n}=18$ ).

\begin{tabular}{lccccccc}
\hline Chicken & \multicolumn{7}{c}{ Weekly Weight Gain (g) } \\
\cline { 2 - 8 } Breeds & $\mathbf{0}$ to $\mathbf{1}$ & $\mathbf{1}$ to $\mathbf{2}$ & $\mathbf{2}$ to $\mathbf{3}$ & $\mathbf{3}$ to $\mathbf{4}$ & $\mathbf{4}$ to 5 & $\mathbf{5}$ to $\mathbf{6}$ & $\mathbf{6}$ to $\mathbf{7}$ \\
\hline Pelung & $11.72 \pm 3.83^{\mathrm{a}}$ & $46.33 \pm 6.46^{\mathrm{b}}$ & $36.50 \pm 9.95^{\mathrm{a}}$ & $60.39 \pm 12.2^{\mathrm{a}}$ & $41.44 \pm 15.04^{\mathrm{a}}$ & $94.44 \pm 32.23 \mathrm{a}$ & $141.72 \pm 47.67 \mathrm{~b}$ \\
Broiler & $40.89 \pm 9.64^{\mathrm{c}}$ & $41.50 \pm 24.08^{\mathrm{b}}$ & $198.17 \pm 59.37^{\mathrm{c}}$ & $199.00 \pm 59.7^{\mathrm{c}}$ & $254.22 \pm 44.51^{\mathrm{c}}$ & $227.61 \pm 66.29^{\mathrm{c}}$ & $297.89 \pm 79.51^{\mathrm{d}}$ \\
Layer & $10.44 \pm 1.58^{\mathrm{a}}$ & $32.39 \pm 6.06^{\mathrm{a}}$ & $35.22 \pm 12.36^{\mathrm{a}}$ & $57.17 \pm 18.54^{\mathrm{a}}$ & $48.06 \pm 16.15^{\mathrm{a}}$ & $98.72 \pm 44.20^{\mathrm{a}}$ & $113.50 \pm 22.66^{\mathrm{a}}$ \\
Hybrid & $19.78 \pm 6.92^{\mathrm{b}}$ & $66.22 \pm 22.76^{\mathrm{c}}$ & $55.94 \pm 18.68^{\mathrm{b}}$ & $100.72 \pm 34.13 \mathrm{~b}$ & $201.06 \pm 42.53 \mathrm{~b}$ & $171.50 \pm 54.56^{\mathrm{b}}$ & $236.61 \pm 77.32^{\mathrm{c}}$ \\
\hline
\end{tabular}

a-d Means with the different superscripts in the same column are significantly different $(\mathrm{p}<0.05)$.

second place starting from week two until week seven. This data indicates that hybrid chicken had a better growth rate than layer and pelung and might be a better alternative for meat-type chicken.

The breast muscle yield and carcass quality of all chicken types at week seven are presented in Table 6 . The breast yield and protein of broiler presented in Table 6 were significantly the highest compared to the other types. On the other hand, the layer showed the highest $\mathrm{pH}$ value and moisture. Pelung was observed to have the highest fat content and the lowest $\mathrm{pH}$ value among all chicken types. The hybrid type showed higher breast muscle weight than layer and pelung types and lower fat content than the broiler type. However, there was no significant difference in collagen among those four types $(p>0.05)$.

Breast muscle is frequently used in many research types as one of skeletal muscle development and poultry meat quality indicators. The breast yield measurement resulted in this research show that the broiler group has the highest breast yield percentage, followed by hybrid and layer groups. This finding agrees with Fanatico et al. (2005) reported that stated a fast-growing broiler obtains the highest breast yield percentage compared to the slow- and medium-growing broiler. Several genes affecting breast yield have been reported, such as insulin-like growth factor 1 (Sato et al. 2012), growth hormone receptor (Khaerunnisa et al. 2017), and chicken growth hormones (Anh et al. 2015). On the other hand, Berri et al. (2007) reported that high breast yield is associated with large fibre cross-sectional area and high $\mathrm{pH}$ post-mortem value, leading to better adaptation to further process of the meat.

One of the important factors determining chicken meat quality is its $\mathrm{pH}$ value (Le Bihan-Duval et al. 2008). After slaughter, oxygen availability is limited and causes the escalation of lactic acid production. Lactic acid accumulation in muscle causes the $\mathrm{pH}$ drops. It leads to protein denaturation, decreasing the protein solubility, and overall results in the decrease of the protein reactive sites, which play a role in water binding in the muscle protein. Low $\mathrm{pH}$ in meat causes the meat's protein to disperse, thus causing the light to bounce off and reflects pale colour (Mir et al. 2017).

The $\mathrm{pH}$ of the chicken meats observed in this research was diverse. Pelung had the lowest $\mathrm{pH}$ value among all types, while the layer had the highest $\mathrm{pH}$. No significant difference was analysed in the $\mathrm{pH}$ of broiler and 
Table 6. Breast muscle yield and carcass quality among chicken breeds on week $7(n=6)$.

\begin{tabular}{lccccccc}
\hline $\begin{array}{c}\text { Chicken } \\
\text { Breeds }\end{array}$ & $\begin{array}{c}\text { Breast Muscle } \\
\text { Weight (g) }\end{array}$ & $\begin{array}{c}\text { Breast Yield } \\
\mathbf{( \% )}\end{array}$ & $\mathbf{p H}$ & $\begin{array}{c}\text { Collagen } \\
\mathbf{( \% )}\end{array}$ & Fat (\%) & Moisture (\%) & Protein (\%) \\
\hline Pelung & $30.833 \pm 3.03^{\mathrm{a}}$ & $5.66 \pm 1.84^{\mathrm{a}}$ & $5.35 \pm 0.19^{\mathrm{a}}$ & $1.43 \pm 0.33$ & $4.27 \pm 0.73^{\mathrm{a}}$ & $74.63 \pm 1.40^{\mathrm{a}}$ & $21.58 \pm 0.35^{\mathrm{b}}$ \\
Broiler & $283.500 \pm 31.73^{\mathrm{c}}$ & $21.81 \pm 1.20^{\mathrm{c}}$ & $5.61 \pm 0.03^{\mathrm{b}}$ & $1.41 \pm 0.18$ & $2.11 \pm 0.79^{\mathrm{b}}$ & $73.22 \pm 0.34^{\mathrm{b}}$ & $22.36 \pm 0.68^{\mathrm{a}}$ \\
Layer & $39.640 \pm 3.94^{\mathrm{a}}$ & $9.083 \pm 0.95^{\mathrm{b}}$ & $5.66 \pm 0.04^{\mathrm{c}}$ & $1.43 \pm 0.11$ & $1.51 \pm 0.37^{\mathrm{c}}$ & $74.12 \pm 0.46^{\mathrm{a}}$ & $21.88 \pm 0.48^{\mathrm{b}}$ \\
Hybrid & $90.500 \pm 6.18^{\mathrm{b}}$ & $10.71 \pm 3.12^{\mathrm{b}}$ & $5.57 \pm 0.04^{\mathrm{b}}$ & $1.49 \pm 0.05$ & $1.54 \pm 0.25^{\mathrm{c}}$ & $73.94 \pm 0.84^{\mathrm{b}}$ & $21.39 \pm 0.70^{\mathrm{b}}$ \\
\hline
\end{tabular}

a-c Means with the different superscripts in the same column are significantly different $(p<0.05)$.

hybrid chicken. These findings are aligned with the research conducted by Berri et al. (2007) that concluded that low post-mortem pH is associated with high post-mortem muscle glycolytic potential that causes high lactate content in muscle with small fibre cross-sectional area. The chicken, which has low $\mathrm{pH}$, uses carbohydrate metabolism as the energy production process. On the other hand, chicken with high $\mathrm{pH}$ uses alternative catabolic pathways, compromising its muscle development and integrity (Beauclercq et al. 2017).

Another factor that determines the texture, and generally the meat quality of the chicken, is collagen. Collagen is the main component in intramuscular connective tissue that determines muscle hardness (Torrescano et al. 2003). Moreover, moisture plays a role in determining the meat tenderness, juiciness, firmness, and appearance that is important to the meat quality and economic value (Mir et al. 2017).

Intramuscular fat (IMF) definition refers to the fat that is deposited between myofibers. The IMF plays a crucial role in defining meat characteristics such as meat tenderness, juiciness, taste, and consumers' acceptability (Guo-Bin et al. 2010). Liu et al. (2017) reported that IMF deposition starts from incubation day 17 until post-hatch day one and is regulated by the fatty acid pathway's beta-oxidation. Several factors are reported affecting IMF content, such as sex (Guo-Bin et al. 2010), age (Liu et al. 2016; Decai et al. 2017), genetics (Ye et al. 2014), and muscle type (Hocquette et al. 2010). The results of this study showed that hybrid chicken contained lower fat content $(1.54 \pm 0.25 \%)$ compared to broiler and pelung, with no significant difference with layer $(p>0.05)$ on the same age and the same feeding. This finding is in agreement with the research by Liu et al. (2019) that reported nine genes were related to differential IMF deposition between chicken breeds.

The body growth, breast yield, and meat characteristics of the hybrid chicken derived from crossing between pelung, broiler, and layer chickens show intermediate characteristics resulting from the combination of the elder chickens. The results from this study showed the pelung hybrid chicken had lower body weight on week 7 (888.22 \pm 139.63 gram) compared to broiler

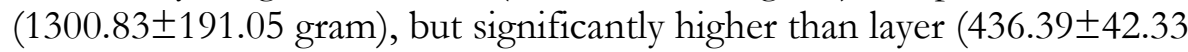
gram) and pelung (467.06 \pm 85.7 gram; $p<0.05)$. The pelung hybrid chicken meat contained $1.54 \pm 0.25 \%$ fat, which was lower than pelung $(4.27 \pm 0.73 \%)$ and broiler $(2.11 \pm 0.79 \%)$. Pelung hybrid had $5.57 \pm 0.04 \mathrm{pH}$ value which was higher than the pelung had $(5.35 \pm 0.19)$ as well. On the other hand, pelung hybrid had lower protein content $(21.39 \pm 0.70 \%)$ than broiler $(22.36 \pm 0.68 \%)$ significantly $(p<0.05)$. Breast yield of the hybrid chicken was $10.71 \pm 3.12 \%$, which was significantly higher than pelung $(5.66 \pm 1.84 \% ; p<0.05)$. These characteristics of hybrid chicken breast muscle led to the conclusion that hybrid chicken is a potential alternative meat-type chicken with local chicken meat characteristics and faster growth than slow-type chickens such as layer and pelung. 


\section{AUTHORS CONTRIBUTION}

U.E.P conducted the research, data analysis and wrote the manuscript, H.T.S.S.G.S supervised the research and manuscript writing, T.H. and B.S.D. supervised and designed the research.

\section{ACKNOWLEDGMENTS}

This research was supported by PMDSU research grant 2018 No. 2014/UN/ DITLIT/DIT-LIT/LT/2018 funded by the Ministry of Research, Technology, and Higher Education of Indonesia.

\section{CONFLICT OF INTEREST}

The authors declare there is no conflict of interest.

\section{REFERENCES}

AOAC International, 2007, AOAC official method 2007.04 fat, moisture, and protein in meat and meat products. Journal of $A O A C$ International, 90, pp.1073.

Anh, N.T.L, Kunhareang, S. \& Duangjindam, M., 2015, Association of chicken growth hormones and insulin-like growth factor gene polymorphisms with growth performance and carcass traits in Thai broilers. Asian-Australasian Journal of Animal Science, 28, pp.1686-1695.

Barbic, J., Milicevic, D., Vrani, D., Lukic, M. \& Petrovic, Z., 2014, The effect of season of transportation on the welfare of broilers and selected parameters of broilers meat quality. Tehnologija Mesa, 55(1), pp.46-53.

Beauclercq, S. et al., 2017, Muscle transcriptome analysis reveals molecular pathways and biomarkers involved in extreme ultimate $\mathrm{pH}$ and meat defect occurrence in chicken. Scientific Reports, 7, pp.6447.

Berri, C. et al., 2001, Effect of selection for improved body composition on muscle and meat characteristics of broilers from experimental and commercial lines. Poultry Science, 80, pp.833-838.

Berri, C. et al., 2007, Consequence of muscle hypertrophy on characteristics of Pectoralis major muscle and breast meat quality of broiler chickens. Journal of Animal Science, 85, pp.2005-2011.

Buzala, M., Janicki, B. \& Czarnecki, R., 2015, Consequences of different growth rates in broiler breeders and layer hens on embryogenesis, metabolism, and metabolic rate: a review. Poultry Science, 94, pp.728733.

Decai, X. et al., 2017, Correlation analysis of relative expression of Apob, Adfp, and Fatp1 with lipid metabolism in Daweishan mini chickens. Brazilian Journal of Poultry Science, 19, pp.151-158.

Dixon, L.M., Sparks, N.H.C. \& Rutherford, K.M.D., 2016, Early experiences matter: a review of the effects of prenatal environment on offspring characteristics in poultry. Poultry Science, 95, pp. 489-499.

Everaert, N. et al., 2010, The effect of the protein level in a pre-starter diet on the post-hatch performance and activation of ribosomal protein S6 kinase in muscle of neonatal broilers. British Journal of Nutrition, 103, pp.206-211.

Fanatico, A.C., Cavitt, L.C., Pillai, P.B., Emmert, J.L. \& Owens, C.M., 2005, Evaluation of slower-growing broiler genotypes grown with and without outdoor access: meat quality. Poultry Science, 84, pp. 1785-1790.

Guo-Bin, C. et al., 2010, Developmental rule of intramuscular fat content in chicken. Journal of Animal and Veterinary Advances, 9, pp.297-298.

Hocquette, J.F. et al., 2010, Intramuscular fat content in meat-producing animals: development, genetic and nutritional controls, and identification of putative markers. Animal, 4, pp.303-319. 
Khaerunnisa, I. et al., 2017, The associations of GH and GHR genes with carcass components in Indonesian kampung and Broiler chicken cross. Media Peternakan, 40, pp.78-87.

Le Bihan-Duval, E. et al., 2008, Chicken meat quality: genetic variability and relationship with growth and muscle characteristics. BMC Genetics, 9, pp.53.

Liu, L. et al., 2016, Intramuscular fat accumulation at different post-hatching ages in chickens. PLOS One, 11, e0159722.

Liu, L., Cui, H., Fu, R., Zheng, M., Liu, R., Zhao, G. \& Wen, J., 2017, The regulation of IMF deposition in pectoralis major of fast- and slowgrowing chickens at hatching. Journal of Animal Science and Biotechnology, 8, pp. 77-84.

Liu, L. et al., 2019, Effect of divergent selection for intramuscular fat accumulation at different post-hatching ages in chickens. PLOS One, 11, e0159722.

Lonergan, S.M. et al., 2003, Breast meat quality and composition in unique chicken populations. Poultry Science, 82(12), pp.1990-1994.

Milicevic, D. et al., 2015, Physicochemical and functional properties of chicken meat. Procedia Food Science, 5, pp.191-194.

Mir, N.A. et al., 2017, Determinants of broiler chicken meat quality and factors affecting them: a review. Journal of Food. Science and Technology, 54 (10), pp. 2997-3009.

Nataamijaya, A.G., 2010, Development of native chicken potential to improve farmer's welfare. Jurnal Pengembangan Pertanian, 29, pp.131-138. (Indonesian version).

Pauwels, J. et al., 2015, Selection for growth performance in broiler chickens associates with less diet flexibility. PLOS One, 10, e0127819.

Petracci, M. et al., 2015, Meat quality in fast-growing broiler chickens. Worlds Poultry Science Journal, 71, pp.363-374.

Puspita, U.E. et al., 2017, Effect of varying levels of protein and energy in pre-starter feeds on pectoralis muscle development of Kampung Super chicks (Gallus gallus gallus). Asian Journal of Animal and Veterinary Advances, 12, pp.31-37.

Saragih, H.T.S.G., Roosdianto, I., \& Daryono, B. S., 2017, Pectoralis thoracicus muscle performance of hybrid chicken $\left(F_{1}\right)$ derived from crossbreed between broiler and pelung (Gallus gallus gallus). Jurnal Kedokteran Hewan, 11, pp.62-64.

Saragih, H.T.S.G. et al., 2019, Phenotypic characteristics of exotic-broiler, kampung, male exotic-layer, KUB-1, and pelung chickens. Jurnal Ilmu Ternak dan Veteriner, 24, pp.9-14.

Sato, K. et al., 2012, Polymorphism of insulin-like growth factor 1 gene is associated with breast muscle yields in chickens. Animal Science Journal, 83, pp.1-6.

Sokolowicz, Z., Krawczyk, J. \& Świątkiewicz, S., 2016, Quality of poultry meat from native chicken breeds-a review. Annals of Animal Science, 16, pp.347-368.

Torrescano, G. S., Sánchez-Esalante, A., Giménez, B., Roncalés, P. \& Beltrán, J.A, 2003, Shear values of raw samples of 14 bovine muscles and their relation to muscle collagen characteristics. Meat Science, 64, pp. 85-91.

Velleman, S.G., 2007, Muscle development in the embryo and hatchling. Poultry Science, 6, pp. 1050-1054.

Wang, S.Z. et al., 2012, Quantitative trait loci associated with body weight and abdominal fat traits on chicken chromosomes 3,5 and 7. Genetics and Molecular Research, 11, pp.956-965. 
Ye, Y. et al., 2014, Analysis of differentially expressed genes and signaling pathways related to intramuscular fat deposition in skeletal muscle of sex-linked dwarf chickens. BioMed Research International, 2014, pp.1-7. 